\title{
FLOW CHARACTERISTICS OF HYDRO-GENERATOR QHD 17 INDEPENDENCE ON THE CHANGE OF PHYSICAL PROPERTIES OF HYDRAULIC FLUID
}

\author{
Hujo L..", Jablonický J.**, Kaszkowiak J.***
}

\begin{abstract}
The flow characteristics of the hydrogenator QHD 17 were measured in laboratory conditions using hydraulic-transmission liquid MOL farm NH Ultra. Testing of the aforementioned hydraulic-transmission fluid was carried out on a laboratory testing device, which allows to test hydrostatic transducers and transmissionhydraulic fluids. Results of the research include evaluation of flow properties of hydro-generator and flow efficiency, the physical properties of the testing transmission-hydraulic fluid.
\end{abstract}

\section{Keywords: Hydrostatic transducers, Hydro-generator flow, Transmission-hydraulic fluid, Taboratory research, Physical properties.}

\section{Introduction}

Changes in the physical properties of the operational fluid significantly affects the flow characteristics of the hydro-generator, regardless of the operating time. There are high demands on fluids, which serve as energy carriers in hydraulic systems (Tulík et al., 2015). We also consider the impact of these fluids on the environment. Due to shortened testing of hydrostatic transducer with different types of operational fluid, we used accelerated fluid testing and simulation of operating load of the hydro-generator in laboratory condition.

\section{Methods}

Laboratory test equipment allows simulation of operating load of transmission hydro-generator, which was used in hydraulic system of tractor during application of testing hydraulic fluid. The measuring technology, which is part of the hydraulic circuit, consist of a flow sensor, pressure sensor and temperature sensor. This equipment is interconnected with recording unit HMG 3010, which allows flow measurements in the range of 6 to $60 \mathrm{dm}^{3} \cdot \mathrm{min}^{-1}, 15$ to $300 \mathrm{dm}^{3} \cdot \mathrm{min}^{-1}$ and 40 to $600 \mathrm{dm}^{3} \cdot \mathrm{min}^{-1}$ during a pressure of up to $40 \mathrm{MPa}$ and temperature up to $100^{\circ} \mathrm{C}$.

The laboratory test of the oil MOL farm NH Ultra was carried out based on the chosen methodical procedure:

- provision of a reference sample and its analysis of physical-chemical properties,

- the first measurement was performed in the range of 125 hours worked and the signal data from the flow sensor, pressure sensor and temperature sensor were recorded, during hydro-generator rotation $500,750,1000,1250,1500,1750,2000,2250$ and $1750 \mathrm{rpm}$,

- samples of the test fluid should be taken before the next set of measurements, further sampling of the test fluid are realized after 250, 375 and 500 hours worked,

- the fluid samples, after processing the aforementioned number of hours, were subjected to physicalchemical analysis.

\footnotetext{
Assoc. Prof. Ing. Lubomír Hujo, PhD.: Faculty of Engineering, Slovak University of Agriculture, Tr. A. Hlinku 2; 949 01, Nitra; SK, lubomir.hujo@uniag.sk

** Assoc. Prof. Ing. Juraj Jablonický, PhD.: Faculty of Engineering, Slovak University of Agriculture; Tr. A. Hlinku 2; 949 01, Nitra; SK, juraj.jablonicky@uniag.sk

*** Dr Inż. Jerzy Kaszkowiak: Faculty of Mechanical Engineering, University of Science and Technology Bydgoszcz; Street Kaliskiego 7; 85-789, Bydgoszcz; PL, jerzy.kaszkowiak@utp.edu.pl
} 
The methodological procedure for sampling the hydraulic fluid to be tested followed the standard STN 65 6207 (Hydraulic oils and fluids. Sampling for determination of mechanical impurities.). In order to assess the suitability of the tested hydraulic fluid in hydraulic circuits of different machineries, it is necessary to know the input parameters of the system and technical parameters of the hydrogenerator, which will be connected in the hydraulic circuit during testing (Tab. 1).

Tab. 1: Parameters of the hydro-generator QHD 17.

\begin{tabular}{|c|c|c|c|c|}
\hline \multicolumn{2}{|c|}{ Parameters } & Identification & Units & Values \\
\hline Actual geometric volume & $\mathrm{V}_{\mathrm{g}}$ & $\mathrm{dm}^{3}$ & $17.24 \times 10^{-3}$ \\
\hline \multirow{2}{*}{ Torque } & nominal & $\mathrm{n}_{\mathrm{n}}$ & $\mathrm{rpm}$ & 1500 \\
\hline \multirow{3}{*}{ Outlet pressure } & minimum & $\mathrm{p}_{1 \min }$ & $\mathrm{MPa}$ & -0.03 \\
\cline { 2 - 5 } & maximum & $\mathrm{p}_{1 \max }$ & $\mathrm{MPa}$ & 0.05 \\
\cline { 2 - 5 } & maximum continuous & $\mathrm{p}_{2 \mathrm{n}}$ & $\mathrm{MPa}$ & 29 \\
\cline { 2 - 5 } & maximum & $\mathrm{p}_{2 \max }$ & $\mathrm{MPa}$ & 31 \\
\hline Nominal output flow (min.) during $\mathrm{n}_{\mathrm{n}}$ and $\mathrm{p}_{2 \mathrm{n}}$ & $\mathrm{p}_{3}$ & $\mathrm{MPa}$ & 32 \\
\hline \multicolumn{2}{|c|}{ Maximum flow during $\mathrm{n}_{\max }$ and $\mathrm{p}_{2 \max }$} & $\mathrm{Q}_{\max }$ & $\mathrm{dm}^{3} \cdot \mathrm{min}^{-1}$ & 23.2 \\
\hline \multicolumn{2}{|c|}{ Nominal input (max.) during $\mathrm{n}_{\mathrm{n}}$ and $\mathrm{p}_{2 \mathrm{n}}$} & $\mathrm{P}_{\mathrm{n}}$ & $\mathrm{kW}$ & 54.3 \\
\hline \multicolumn{2}{|c|}{ Maximum input during $\mathrm{n}_{\max }$ and $\mathrm{p}_{2 \max }$} & $\mathrm{P}_{\max }$ & $\mathrm{kW}$ & 14.8 \\
\hline \multicolumn{2}{|c|}{ Weight } & $\mathrm{m}$ & $\mathrm{kg}$ & 10.9 \\
\hline
\end{tabular}

Tested operational fluid is MOL Farm NH Ultra, transmission-hydraulic fluid developed for machines by Case New Holland Group, gearboxes, power - shift gearboxes, differentials, wet brakes and hydraulic systems used in high-performance agricultural machinery. Density at $15{ }^{\circ} \mathrm{C}$ is $875 \mathrm{~kg} \cdot \mathrm{m}^{-3}$. Kinematic viscosity at $40{ }^{\circ} \mathrm{C}$ is $64.2 \mathrm{~mm}^{2} \cdot \mathrm{s}^{-1}$. Kinematic viscosity at $100{ }^{\circ} \mathrm{C}$ is $10,9 \mathrm{~mm}^{2} \cdot \mathrm{s}^{-1}$. Viscosity index is 162 . Pour point is $-36{ }^{\circ} \mathrm{C}$. Flash point in open cruicble is $210{ }^{\circ} \mathrm{C}$. The fluid is blue in color, transparent, homogeneous and liquid.

\section{Conclusions}

The measured values of the tested hydraulic fluid are listed in Tab. 2 depending on the number of hours worked. The density of the fluid may be affected by the presence of abrasive metals or environmental impurities.

Tab. 2: The physical properties of the hydraulic fluid under test - MOL Farm NH Ultra.

\begin{tabular}{|c|c|c|c|c|c|c|c|}
\hline \multirow{2}{*}{ Method } & \multirow{2}{*}{ Parameter } & \multirow{2}{*}{ Units } & \multicolumn{5}{|c|}{ Sampling interval } \\
\cline { 4 - 8 } & & & $\mathbf{0 ~ h}$ & $\mathbf{1 2 5} \mathbf{~ h}$ & $\mathbf{2 5 0} \mathbf{~ h}$ & $\mathbf{3 7 5} \mathbf{~ h}$ & $\mathbf{5 0 0} \mathbf{~ h}$ \\
\hline \multirow{3}{*}{$\begin{array}{c}\text { ASTM } \\
\text { D7042 }\end{array}$} & Density at $40^{\circ} \mathrm{C}$ & $\mathrm{kg} \cdot \mathrm{m}^{-3}$ & 860.70 & 860.65 & 860.66 & 860.60 & 860.62 \\
\cline { 2 - 8 } & Dynamic viscosity at $40^{\circ} \mathrm{C}$ & $\mathrm{mPa} . \mathrm{s}$ & 49.00 & 47.10 & 46.50 & 46.56 & 46.05 \\
\cline { 2 - 8 } & Kinematic viscosity at $40^{\circ} \mathrm{C}$ & $\mathrm{mm}^{2} \cdot \mathrm{s}^{-1}$ & 56.90 & 54.80 & 54.00 & 54.10 & 53.50 \\
\hline \multicolumn{2}{|c|}{ Acid number ASTM D664 A } & $\mathrm{mgKOH} . \mathrm{g}^{-1}$ & 2.91 & 3.29 & 3.36 & 3.59 & 3.67 \\
\hline \multicolumn{2}{|c|}{ Water content DIN 51777 } & $\%$ & 0.07 & 0.05 & 0.04 & 0.05 & 0.04 \\
\hline
\end{tabular}

The viscosity may incerase or decrease during use. The increase may be caused by oxidtaion products or impurities in the fluid (Helebrant et al., 2001). On the contrary, it is decrease is mainly due to mechanical and thermal degradation of the additive. Flow characteristics of QHD 17 with MOL Farm NH Ultra tested as a function of hours worked fort rotation ranging from $500 \mathrm{rpm}$ to $2750 \mathrm{rpm}$. The results of the measured data processing are recorded in the Fig. 1 for the nominal hydrogenrator rotation $1500 \mathrm{rpm}$. 


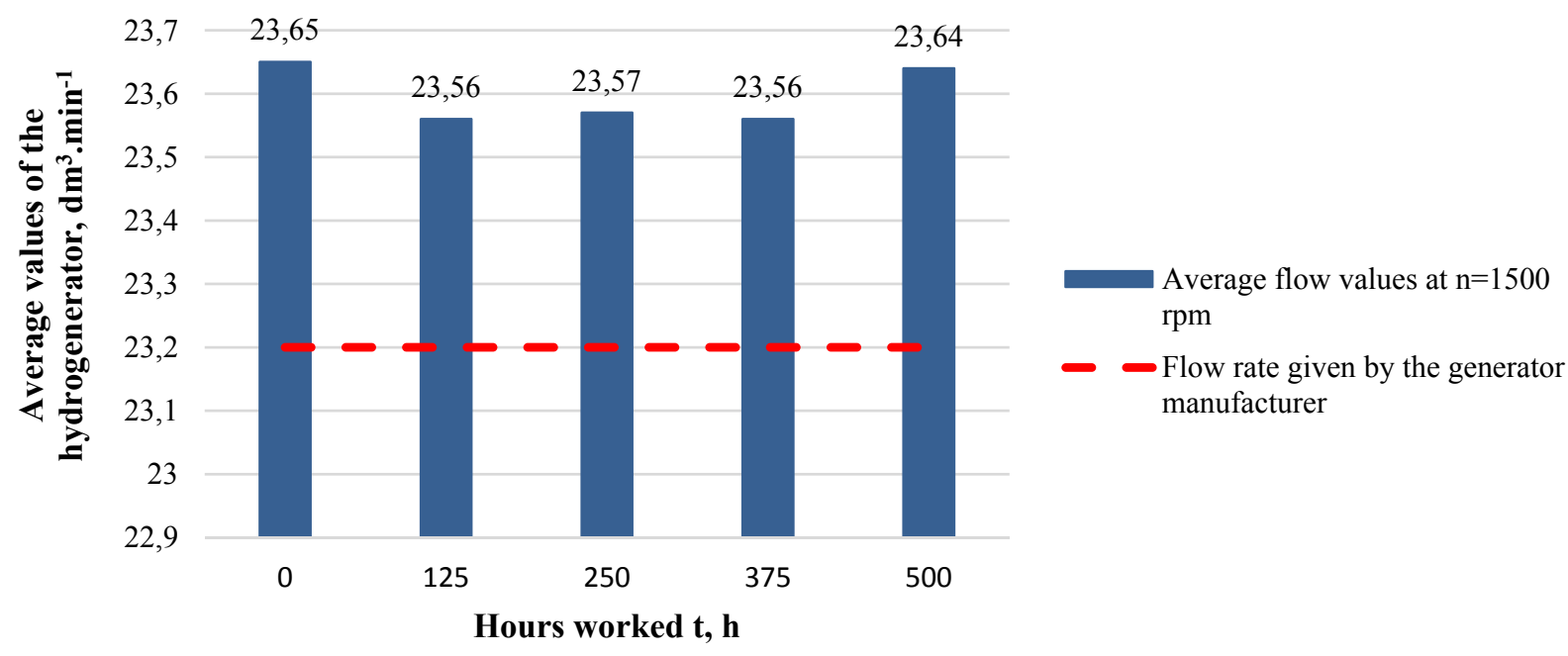

Fig. 1: Dependence of average flow value QHD 17 during test with tested transmission-hydraulic fluidrotation $1500 \mathrm{rpm}$.

The maximum decrease in flow efficiency was $0.37 \%$ after 375 hours worked. After 500 hours worked, there was a decrease in flow efficiency compared to 0 hours worked only $0.03 \%$. The graphical dependencies of Fig. 2 is processed at $1500 \mathrm{rpm}$, since at the rotation the manufacturer has determined the rated parameters of the hydrogenerator.

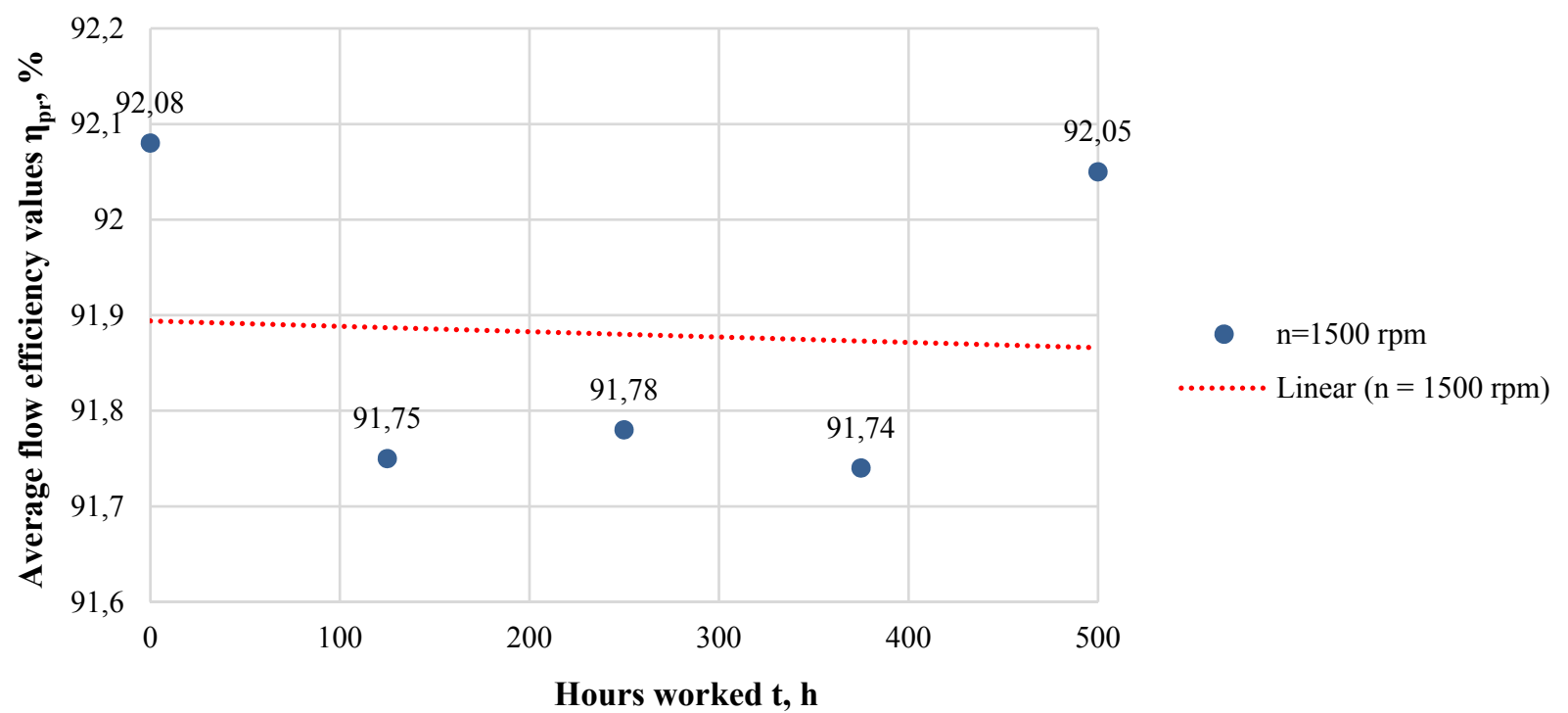

Fig. 2: Dependence of average values of flow efficiency QHD 17 during the test with tested transmissionhydraulic fluid - rotation $1500 \mathrm{rpm}$.

Aforementioned statement can be confirmed in accordance with ISO 15380: 2011. The operational fluid does not affect the flow properties of the hydro-generator QHD 17 or any other component. Therefore, the flow efficiency did not decrease by more than $20 \%$.

It can be stated from the relation between the average flow rate of the hydro-generator and the number of hours worked, that the physical-chemical composition of the tested hydraulic oil MOL Farm NH Ultra has no negative effect on the flow properties of the QHD 17 or the other components of the transmissionhydraulic system on the tested equipment. Contamination of the working fluid causes accelerated wear of the hydraulic system, corrosion of steel surfaces, oxidation of fluid and a list of its physical and chemical properties (Čorńák, 2018). Pollution mainly affects ecological fluids, which speeds up their degradation processes (Zastempewski, 2013). Several authors are involved in the evaluation of hydraulic fluid during the operational test with subsequent analysis of contaminants, for example Kučera et al. (2016) and Tulík et al. (2016). As Simikić et al. (2014) says, machines working in agriculture are characterized by demanding operation, often work in dusty and humid environment, which negatively affects the contamination of fluid 
fillings. The use of environmentally friendly fluids requires a high degree of purity of the fluid filling and a non-measurable concentration of water (Tulík et al., 2015). For this reason, it is important to accurately machine the individual components of the hydraulic circuit, where it is important to monitor the accuracy of CNC machine tools using new methods and trends in product development and planning, where equally important is the multicriterial diagnostics of CNC machines (Košinár and Kuric, 2011 and Kuric et al., 2016). The new QHD17 hydro-generator was also tested during MOL Farm NH Ultra transmissionhydraulic fluid testing. Flow and flow efficiency values are also used to create dynamic flow models in hydrostatic transducers using numerical simulation to protect the environment (Puškár et al., 2015 and Puškár et al., 2019).

\section{Acknowledgement}

This work was supported by project VEGA 1/0155/18 „Applied research of the use of ecological energy carriers in agricultural, forestry and transport technology. "

This work was supported by project KEGA 028SPU-4/2019 „Practical utilization of design and testing knowledge of transmission systems of hydraulic mechanisms of mobile agricultural and forestry machinery."

This work was supported by project APVV SK-PL-18-0041 „The Development of Scientific Cooperation in the Study of the Effects of Biofuels in Road Transport, Including Environmental Impact".

\section{References}

Čornák, Š. (2018) Identification of operating fluids with fingerprint method utilization. In: 17th International Scientific Conference engineering for rural development. Jelgava: Latvia University of Agriculture, pp. 2048-2053.

Kučera, M., Aleš, Z. and Pexa, M. (2016) Detection and characterization of wear particles of universal tractor oil using of particles size analysis. Agronomy Research 14(4), pp. 1351-1360.

Košinár, M. and Kuric, I. (2011) Monitoring of CNC machine tool accuracy. In: 1st International Conference on Quality and Innovation in Engineering and Management (QIEM), pp. 115-118.

Kuric, I., Zajačko, I. and Císar, M. (2016) Analytical Intelligence tools for multicriterial of CNC machines. In: Advances in Science and Technology research journal, 10 (32): pp. 59-64.

Puškár, M., Brestovič, T. and Jasminská, N. (2015) Numerical simulation and experimental analysis of acoustic wave influences on brake mean effective pressure in thrust-ejector inlet pipe of combustion engine. In: International Journal of Vehicle Design, 67 (1), pp. 63-67.

Puškár, M., Jahnátek, A., Kuric, I., Kádárová, J., Kopas, M. and Šoltésová, M. (2019) Complex analysis of influence of biodiesel and its mixture on regulated and unregulated emissions of motor vehicles with the aim to protect air quality and environment. In: Air Quality, Atmosphere \& Health, 12 (7), pp. 855-864.

Simikić, M., Dedović, N., Savin, L., Tomić, M. and Ponjičan, O. (2014) Power delivery efficiency of a wheeled tractor at oblique drawbar force. Soil and Tillage Research 141, pp. 32-43.

Zastempowski, M. (2013) Test stands with energy recovery system for machines and hydraulic transmissions, Journal of Research and Applications in Agricultural Engineering, 58(2), pp. 188-191.

Tulík, J., Halenár, M., Kuchar, P. and Jánošová, M. (2016) Comparison of conventional hydraulic fluid with biodegradable fluid on the basis of laboratory test of durability. In Traktori i pogonske mašine, vol. 21, no. 1, pp. 64-70.

Tulík, J., Kosiba, J., Szabó, M., Varga, F., Kangalov, P. and Mareček, J. (2015) Analysis of new biodegradable fluid during of the operating test. In Agricultural, forest and transport machinery and technologies, vol. 2, iss. 1, pp. 11-15.

Helebrant, F., Ziegler, J. and Marasová, D. (2001) Technical diagnostics and reliability I. Tribodiagnostics. Book, VSB-Technical university, Ostrava (in Czech). 